Int. J. Dev. Biol. 66: 23-33 (2022)

https://doi.org/10.1387/ijdb.210158gk

\title{
Organoids: the third dimension of human brain development and disease
}

\author{
GEORGIA KOUROUPI*, KANELLA PRODROMIDOU, \\ FLORENTIA PAPASTEFANAKI, ERA TAOUFIK, REBECCA MATSAS*
}

Laboratory of Cellular and Molecular Neurobiology - Stem Cells, Hellenic Pasteur Institute, Athens, Greece

\begin{abstract}
Stem cell technologies have opened up new avenues in the study of human biology and disease. In particular, the advent of human embryonic stem cells followed by reprograming technologies for generation of induced pluripotent stem cells have instigated studies into modeling human brain development and disease by providing a means to simulate a human tissue otherwise wholly or largely inaccessible to researchers. Brain development is a complex process achieved in a remarkably controlled spatial and temporal manner through coordinated cellular and molecular events. In vitro models aim to mimic these processes and recapitulate brain organogenesis. Initially, two-dimensional neural cultures presented an innovative landmark for investigating human neuronal and, more recently, glial biology, as well as for modeling brain neurodevelopmental and neurodegenerative diseases. The establishment of three-dimensional cultures in the form of brain organoids was an equally important milestone in the field. Brain organoids mimic more closely the in vivo tissue composition and architecture and are more physiologically relevant than monolayer cultures. They therefore represent a more realistic cellular environment for modeling the cell biology and pathology of the nervous system. Here we highlight the journey towards recapitulating human brain development and disease in a dish, progressing from two-dimensional in vitro systems to the third dimension provided by brain organoids. We discuss the potential of these approaches for modeling human brain development and evolution, and their promising contribution towards understanding and treating brain disease.
\end{abstract}

KEYWORDS: pluripotent stem cells, in vitro modeling, two-dimensional cultures, neurodevelopmental diseases, neurodegenerative diseases

\section{Introduction}

Since their discovery, stem cells have ushered in a new era in regenerative medicine. In particular, due to the limited regenerative capacity of the adult nervous system, the therapeutic potential of stem cells has opened up new perspectives for development of treatment strategies for brain repair after injury or disease. Therefore, the therapeutic use of appropriate populations derived from stem and progenitor cells has been considered for cell-based therapies for neurodegenerative diseases, primarily Parkinson's disease, and brain injuries. Some of these efforts have reached the level of clinical trials. Such studies were originally inspired by the discovery that tissue-specific neural stem cells able to self-renew and differentiate are naturally present in the adult brain throughout life (Doetsch et al. 1999; Kempermann et al. 2004; Kriegstein and Alvarez-Buylla
2009). In rodents, the process of adult neurogenesis, which is the production of new functional neurons that are integrated into established neuronal circuits, mainly occurs in two brain regions: the subventricular zone of the lateral wall in the lateral ventricle, and the subgranular zone of the dentate gyrus in the hippocampus. Extensive investigations suggest that adult neurogenesis in these two brain regions is functionally associated with, and respectively contributes to, the processes of olfaction or learning and memory (Zhao et al. 2008). The search for an equivalent to adult mouse neurogenesis in humans has been a more challenging and controversial issue (Paredes et al. 2018). Nevertheless, several studies

Abbreviations used in this paper: PSCs, pluripotent stem cells; 2D, two-dimensional; 3D, three-dimensional.

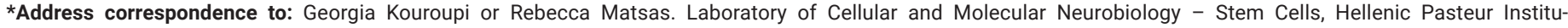

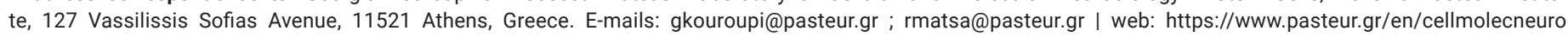
GK: https://orcid.org/00000-0001-6085-3943
}

Submitted: 1 October, 2021; Accepted: 4 October, 2021; Published online: 26 October, 2021. 
support that adult neurogenesis also occurs in the human brain, in the hippocampal area, but this process declines fast with age (Kempermann et al. 2018). Interestingly, neural stem cells both in rodents and in humans can respond to injury or disease by attempting to repair and regenerate the damaged tissue. During this process, which is however not very efficient, neural stem and progenitor cells can differentiate not only into neurons but also into glial cells, depending on the type of injury (Nait-Oumesmar et al. 2007; Benner et al. 2013). For example, in cases in which myelin is destroyed and oligodendrocytes die, as in multiple sclerosis, neural stem cells give rise to new oligodendrocytes to replace those that are lost. These observations have indicated that the adult brain is a far more plastic tissue than originally thought, and have instigated research into enhancing brain regeneration and repair. Two main restorative approaches have been pursued: aiming to increase the beneficial response of endogenous neural stem and progenitor cells, or to replace lost cells by grafting exogenous neural stem cell populations (Björklund and Lindvall 2000; Ottoboni et al. 2020). Cell transplants proved to make a somewhat limited contribution in cell replacement per se, but could significantly enhance the endogenous reparative potential of the damaged brain by secreting growth factors and other regeneration-promoting molecules.

The proliferation versus differentiation potential of neural stem and progenitor cells is of paramount importance for brain homeostasis, but also in a context of injury or disease. We and others have been studying the biology of neural stem cells, and have identified key molecular mechanisms coordinating cell cycle exit and differentiation (Politis et al. 2007; Katsimpardi et al. 2008; Kaltezioti etal. 2010; Prodromidou et al. 2014) aiming at translational approaches for treatment of CNS pathology. We have thus developed therapeutic cell transplantation in pre-clinical mouse models of brain and spinal cord injury, resulting in important anatomical and functional recovery (Papastefanaki et al. 2007; Miltiadous et al. 2013; Papastefanaki et al. 2015; Koutsoudaki et al. 2016). The knowledge garnered from these studies laid the groundwork for transition from mouse models to a human setting, to address specific biological questions that are clinically relevant (Kouroupi et al. 2017; Taoufiketal. 2018; Prodromidou and Matsas 2019;Zygogianni et al. 2019; Prodromidou et al. 2020). Indeed, the advent of human embryonic stem cells followed by reprograming technologies for generation of induced pluripotent stem cells (collectively referred here as pluripotent stem cells; PSCs) has prompted studies into modeling human brain development and disease by providing a means to simulate a human tissue otherwise completely or largely inaccessible to researchers .

\section{Why human models?}

The human brain is a most complex organ, responsible for high-order cognitive functions and social behavior as well as sensory, motor and emotional control, whilst its impairment results in neurodevelopmental, neuropsychiatric and neurodegenerative disorders. It encompasses an unparalleled diversity of neuronal types and subtypes, which arise during development through a series of evolutionary conserved processes, such as progenitor cell proliferation, migration and differentiation, incorporating humanspecific adaptations, including a protracted period of embryonic neurogenesis and the emergence of novel highly heterogeneous progenitor cell populations (Li et al. 2020; Le Bail et al. 2021). Disen- tangling the unique features of the human brain and its vulnerability to neurological disease involves elucidation of the intricate developmental cell transitions orchestrated by progressive molecular events that are tightly controlled in time and space. Rodents have long provided valid proxies for morphological neuroanatomical studies, behavioral paradigms and disease modeling. Nevertheless, a challenging goal of contemporary neuroscience concerns reconstruction of the unique elements that constitute the human brain (Lui et al. 2011). Efforts are directed towards elucidation of species-specific cellular, molecular and biochemical features that shape neuronal connectivity and dictate high-order cognitive functions and social behavior. The basic principles of neurogenesis are conserved across species and include proliferation and diversification of neural progenitor cells that give rise to an extensive array of distinct neuronal and glial phenotypes (Lodato and Arlotta 2015). However, the mouse brain is much smaller, with just 14 million cortical neurons compared with 12 billion in humans, and is lissencephalic (i.e. has a smooth cortical surface), while that of humans is gyrencephalic (i.e. comprises a cortex with multiple convolutions or gyri) (Herculano-Houzel et al. 2006; Herculano-Houzel et al. 2007). Thus, brain evolution has favored expansion of the cortical surface area, along with increase in the radial thickness of the cerebral cortex. This structural innovation is instructive for brain enlargement and involves an expanded primate germinal zone during embryonic development, a region where progenitors reside and proliferate. Consequent evolutionary adaptations incorporate a protracted period of human neurogenesis, and accompanying changes in the morphology and abundance of both excitatory and inhibitory neurons, as well as glial cells, resulting in more complex patterns of synaptogenesis and neuronal connectivity.

Human in vitro models derived from PSCs have progressed significantly in recent years. The derivation of the first human embryonic stem cell lines in 1998 provided a starting point to recapitulate embryonic development and derive a variety of tissue cell types (Thomson et al. 1998). Another breakthrough was the discovery of reprogramming factors to produce induced pluripotent stem cells, which could be generated from a variety of adult somatic cells (Takahashi and Yamanaka 2006). This game-changing technology assuaged ethical concerns associated with the use of human embryonic stem cells and opened the door to pluripotent stem cells from patients, particularly those with genetic disorders, allowing the in vitro study of disease pathogenesis. Finally, the generation of organoids mimicking more closely tissue complexity and spatial organization was a major milestone, allowing to simulate human brain development and disease in three dimensions (Lancaster et al. 2013).

\section{The potential of two-dimensional cultures: lessons learned from Developmental Biology}

The knowledge gained from years of intensive research into the development of various organisms, ranging from Xenopus to mice, was adapted to guide the generation of protocols for 2D cellular systems. A major breakthrough was the establishment of appropriate conditions for PSC culture in an undifferentiated pluripotent state, and the progress made in devising methods for their directed differentiation to neuronal cells based on basic principles of developmental biology. Floating cellular aggregates forming embryoid bodies were induced towards a neural fate, using 

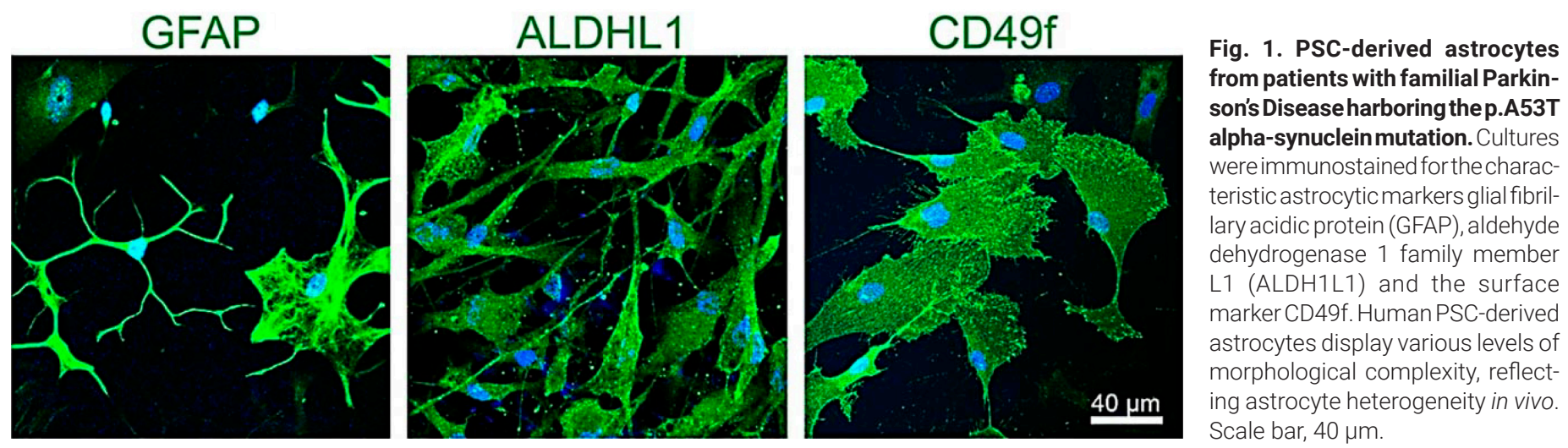

a cocktail of inhibitors suppressing endodermal and mesodermal differentiation, such as dual inhibition of SMAD signaling (Chambers et al. 2009). Embryoid bodies were then seeded as adherent cultures and differentiated into neural precursors, first, and then into neurons, using a mixture of growth factors, including sonic hedgehog $(\mathrm{SHH})$ and fibroblast growth factor $8 \mathrm{~b}$, followed by neuronal maturation factors such as brain-derived neurotrophic factor (BDNF), glial cell-derived neurotrophic factor (GDNF), ascorbic acid (AA) and cyclic AMP (cAMP) (Soldner et al. 2009). The sequence of events taking place in vitro in these cultures recapitulates to a large extent the processes occurring during neurogenesis in vivo and follows the cell-intrinsic transcriptional timing characterizing the various stages of neuronal birth and differentiation. Such cultures are usually composed of a mixture of GABAergic, glutamatergic and to a lesser extent dopaminergic neurons (Kouroupi et al. 2017), but more refined protocols yielding cultures enriched in specific neuronal types, e.g. midbrain dopamine neurons, have also been developed (Kriks et al. 2011).

The cerebral cortex is a laminated structure organized into six layers comprising a large number of neurons that are classically divided into two major types: excitatory glutamatergic pyramidal projection neurons, and inhibitory GABAergic interneurons. Pyramidal neurons comprise the overwhelming majority, amounting to almost $80 \%$ of cortical neurons, and comprise the only output system and the largest input system, conveying information from and to the cerebral cortex. Cortical neurons are further characterized by different molecular and electrophysiological properties, as well as by distinct patterns of synaptic connections. Understanding how this remarkable neuronal diversity is generated and how neural circuits are formed during cortical development remains a challenge, particularly in humans. Interestingly, PSCs have a tendency to differentiate into neural cells in a chemically-defined medium, even in the absence of morphogens, acquiring a dorsal forebrain identity (Gaspard et al. 2008). Thus, it has been possible to simulate cortical development in PSC-derived cultures in a time-dependent fashion, similar to the in vivo situation whereby functional pyramidal neurons are generated sequentially, with deep-layer neurons appearing first, followed by upper-layer neurons, and acquiring molecular identities of all six cortical layers (Gaspard et al. 2008; Espuny-Camacho et al. 2013). After transplantation, such PSC-derived cortical neurons could integrate into the newborn mouse brain and establish specific axonal projections and dendritic patterns corresponding to native cortical neurons (Espuny-Camacho et al. 2013). Moving one step further, the same

group showed that PSC-derived neurons with visual cortex identity could integrate successfully into the lesioned mouse visual cortex after transplantation, whilst transplant maturation was far less efficient into the lesioned motor cortex, indicating that restoration of cortical pathways requires a donor and recipient area-identity match (Espuny-Camacho et al. 2018). These data offer valuable prospects for modeling and treating human diseases associated with cortical dysfunction.

Over the last decade, important efforts have also been made to produce cultures highly enriched in ventral midbrain dopamine neurons, the type of cells that degenerate in Parkinson's disease. Since grafts of human fetal mesencephalic tissue, rich in dopaminergic neurons, in some cases showed had beneficial effects upon patients (Lindvall et al. 1994; Li et al. 2016), cell transplantation has long been considered a promising therapy for Parkinson's disease. Therefore, considerable progress has been made in producing standardized preparations of PSC-derived cells with appropriate midbrain identity in sufficiently large quantities and, importantly, at clinical grade to envisage their transplantation in patients (Barker et al. 2017; Nolbrant et al. 2017). In preparing for human application, several groups have demonstrated that in vitroderived human dopamine neurons are integrated into rodent and primate models of Parkinson's disease and are capable of reversing disease symptoms (Kikuchi et al. 2017; Adler et al. 2019). These studies formed the foundations for the first clinical trials in humans (Schweitzer et al. 2020; Takahashi 2020). In a recent pioneering study, a patient with idiopathic Parkinson's disease received for the first time a transplant of dopamine neurons obtained from in vitro differentiated PSCs, derived from the patient's own skin fibroblasts, without the need for immunosuppression, demonstrating the feasibility of autologous transplantation for dopamine cell replacement (Schweitzer et al. 2020).

The generation and optimization of two-dimensional neuronal cultures has been instrumental in understanding human neuronal development and maturation, but also in modeling and investigating developmental neuropsychiatric brain diseases [for review see (Wang et al. 2020)]. Interestingly, despite the initial concerns over the use of human PSC-based models from patient somatic cells to model age-related neurodegenerative pathologies, such systems were developed for a number of age-related neurodegenerative diseases, including Parkinson's, Alzheimer's and Huntington's diseases or amyotrophic lateral sclerosis, showing multiple phenotypes with considerable relevance for disease pathogenesis and progression. These systems can be of great value in uncovering 
early, potentially triggering, disease mechanisms and assisting in drug discovery [reviewed in (Kouroupi et al. 2020; Trudler et al. 2021)] (Nguyen et al. 2011; Consortium 2012; Chung et al. 2013; Mertens et al. 2013; Ryan et al. 2013; Duan et al. 2014; Balez et al. 2016; Kondo et al. 2017; Kouroupi et al. 2017; Yang et al. 2017; Lin et al. 2018; Antoniou et al. 2022).

Although neuronal cultures derived from PSCs have provided valuable tools for simulating brain development and disease, the contribution of glial cells in these processes is still under study. Recently, the formulation of protocols for producing PSC-derived cultures enriched in astrocytes (Serio et al. 2013; Jones et al. 2017; Tcw et al. 2017; di Domenico et al. 2019; Barbar et al. 2020), oligodendrocytes (Wang et al. 2013; Ehrlich et al. 2017) or microglia (Svoboda et al. 2019; Hasselmann and Blurton-Jones 2020) has emerged, based on developmental principles governing cell fate determination. Yet, there is a clear need for further refinement and optimization in these methods. As glial cells are generated in vivo at a later stage than neurons, one shortcoming is the extensive length of time required for the appearance and maturation of human glial cells in culture. Nevertheless, the first culture and coculture experiments with neurons have seen the light, paving the way for investigation of the critical neuron-glial interactions during development, such as synaptogenesis, neuronal connectivity and myelination, as well as the role of glial cells in brain pathology (Jones et al. 2017; Oksanen et al. 2017; Zhao et al. 2017; Keskin et al. 2019; Narayan et al. 2020; Ponroy Bally et al. 2020).

\section{The third dimension: generation of brain organoids}

While two-dimensional human PSC cultures have provided insights into cell intrinsic phenotypes, particularly in neurons, growing evidence suggested that $3 \mathrm{D}$ cellular aggregate cultures could lead to the generation of more complex tissue structures known as organoids. These could mimic more closely the in vivo tissue composition and architecture, and would therefore be more physiologically relevant than monolayer cultures. Indeed, the self-organizing ability of PSCs in 3D structures has allowed in vitro recapitulation of organogenic processes. Due to the greater diversity of cell composition, the lack of cellular interactions with artificial plastic substrates, and the spontaneous formation of complex 3D structures comparable to those seen in the developing brain, organoids have the potential to create more realistic cellular environments for modeling the cell biology and pathology of the nervous system.

\section{Non-guided and guided methods for organoid generation}

The human brain is a highly complex tissue that can be broadly divided into three regions: the forebrain, midbrain, and hindbrain. In principle, to generate organoids from PSCs, the entire process of brain development should be mimicked as closely as possible. However, this is not possible, as all the cellular and molecular components participating in embryonic brain development cannot be fully substituted. Fortunately, cells in vitro have an inherent potential to differentiate almost spontaneously, as they do in vivo, and with some guidance drawn from basic principles of developmental biology, can attain the desired phenotypes. Since our knowledge of human brain development is limited, the production of human organoids was based on equivalents drawn from mouse development (Kim et al. 2020). The vertebrate central nervous system
(CNS) is derived from the ectoderm, the outermost germ layer of the embryo. During early embryonic development, a part of the dorsal ectoderm becomes specified to neural ectoderm that forms the neural plate, from which the majority of neurons and glial cells originate. Neural stem and progenitor cells can be isolated from the embryonic or adult mouse brain and have the ability to form cellular aggregates in suspension, called neurospheres, which give rise to neuronal and glial progeny (Reynolds and Weiss 1992). Neural aggregates can also be obtained from human PSC-derived free-floating embryoid bodies that are guided to a neuroectodermal lineage (Zhang et al. 2001). Once the cell aggregates acquire the fate of neural progenitors, the remaining developmental steps can occur spontaneously. The realization that human neuroepithelial cells can self-organize to form expandable neural rosettes from PSCs, which contain neural stem and precursor cells surrounding a central lumen resembling the neural tube, was a milestone in the development of three-dimensional organoids (Eiraku et al. 2008; Elkabetz et al. 2008).

The generation of self-organizing optic cups from mouse PSCs was the first entirely 3D neural culture displaying intact tissue architecture (Eiraku et al. 2011). This accomplishment provided the first indication that a free-floating 3D neural culture could self-organize and form histologically accurate tissue architecture. In an unrelated study performed at the same time, the research group led by Hans Clevers reported that adult intestinal stem cells grown in Matrigel, a supportive extracellular matrix gel, could generate remarkably organized $3 \mathrm{D}$ tissues in vitro that resembled the intestinal crypt and epithelium (Sato et al. 2009). A key finding in this study was that embedding epithelial cells in Matrigel provided a suitable environment for self-organization into a 3D structure. Reasoning that the brain also develops as an epithelium and that Matrigel could provide a supportive matrix for epithelia, Lancaster et al developed the first human PSC-derived three-dimensional organoid culture system (Lancaster et al. 2013). Because of lack of inductive signals in the culture medium, the organoids that were produced exhibited a variety of brain regional identities including discrete forebrain, midbrain and hindbrain areas, and even regions with retinal specification.

Unguided brain organoids, produced by spontaneous morphogenesis due to the intrinsic signaling potential of human PSC aggregates, comprise various kinds of neural cell lineages, including neural progenitors, excitatory and inhibitory neurons, astrocytes and oligodendrocyte precursors, providing the opportunity to investigate interactions between different cell types and brain regions (Quadrato et al. 2017; Kanton et al. 2019). However, such spontaneously derived organoids present high intra-and inter-batch variability, making systematic studies very challenging. Variable results are also obtained when different PSC lines are used. These difficulties prompted the guided generation of region-specific organoids, using small molecules and growth factors to promote a certain cell lineage representative of a specific brain region. Thus, organoids with region-specific identities have been produced, such as the forebrain (Mariani et al. 2015), cerebral cortex (Velasco et al. 2019), various telencephalic regions (Kadoshima et al. 2017), hippocampus (Sakaguchi et al. 2015), medial ganglionic eminence (Xiang et al. 2017), midbrain (Jo et al. 2016; Qian et al. 2018; Smits et al. 2019), cerebellum (Muguruma et al. 2015), and choroid plexus-cerebrospinal fluid organoids (Pellegrini et al. 2020). Single cell profiling for transcriptomic and epigenomic analyses 
has been instrumental in identification of the cell types present in such in vitro 3D cultures and their comparison with the in vivo human brain tissue. Moreover, pseudotemporal cell trajectories have been created to reconstruct hierarchical gene expression patterns and cellular specification during human brain development. Camp et al. pioneered the use of scRNA-seq technology to characterize brain organoids (Camp et al. 2015). Although in this study only 333 cells were captured, the authors were able to provide the first evidence that brain organoids recapitulate gene expression programs seen in human fetal cortex development. Subsequently, in a high throughput study, Quadrato et al. analyzed more than 80,000 cells from 31 individual organoids, providing evidence that organoids can generate a broad diversity of cells, related to endogenous types, including cells from the cerebral cortex and the retina (Quadrato et al. 2017). Organoids could be maintained over extended periods, reaching maturation levels not previously attainable, including the formation of dendritic spines in neurons and the generation of spontaneously-active neuronal networks. Notably, neuronal activity could be controlled using light stimulation of photoreceptor-like cells (Quadrato et al., 2017). Remarkably, single cell profiling of human, chimpanzee and macaque organoids illuminated dynamic gene-regulatory features that are unique to humans, most strikingly a slower pace of human neuronal development relative to the other two primates, and divergence in chromatin accessibility that correlated with human-specific gene expression and genetic change (Kanton et al. 2019).

Glial cells are gaining increasing attention because of the important roles they play in neuronal development and disease. In fact, it has been proposed that not only are the properties of neurons unique to the human brain, but also that differences in the number and properties of glial cells account for unique human brain characteristics and cognition. Astrocytes interact extensively with neurons to influence their development and maturation, as well as synapse formation and maintenance. Because they are generated later than neurons and take long to mature, it has been difficult to study human astrocytes in a native environment. By allowing human cerebral cortical spheroids derived from PSCs to develop and mature in vitro for months to years, Sloan and colleagues were able to monitor the development of astrocytes and characterize their functional properties. It was thus shown that human organoid-derived astrocytes were able to induce synapse formation, take up glutamate and synaptosomes, and increase the amplitude of calcium dynamics in human neurons (Sloan et al. 2017). Three-dimensional human brain organoids containing oligodendrocytes as well as neurons and astrocytes have also been developed to assist in investigating human oligodendrogenesis and understanding the mechanisms underlying white matter disorders (Marton et al. 2019).

Guiding organoids towards the neuroectodermal lineage excludes generation of non-ectodermal cell types, such as mesodermal-derived microglia, the resident immune cells of the brain that play an important role in brain development, function and pathology. One approach to incorporate microglia in organoids and study their interaction with neural cells has been to generate human PSC-derived microglia separately and let them infiltrate and integrate into brain organoids. This method permitted the study of microglial morphology, migration, and response to injury in a complex, human 3D cellular environment (Abud et al. 2017). Interestingly, Ormel et al. showed that microglia can also develop innately within cerebral organoids generated without dual SMAD inhibition, and display their characteristic ramified morphology, molecular phenotype and function (Ormel et al. 2018)

\section{Brain assembloids}

Organoid methodology has been evolving, to reflect the cellular complexity of the human brain. A relatively simple approach has been to mix different cell types before aggregates are formed, as in the case of cortical organoids with vasculature-like structures that enhanced their survival and maturation (Cakir et al. 2019). However, such systems cannot achieve a defined spatial organization echoing the in vivo brain architecture. To study spatially organized processes during development, such as neuronal migration and connectivity, the so-called assembloids were devised via a fusion of brain organoids with different regional identity. In this regard, the Pasca lab has generated three-dimensional spheroids from human PSCs that resemble either the dorsal or the ventral forebrain, respectively, containing cortical glutamatergic or GABAergic neuronal progenitors. When these region-specific forebrain organoids were assembled in vitro, they could recapitulate the migratory behavior of interneurons observed in the fetal forebrain (Birey et al. 2017; Xiang et al. 2017). Notably, after migration, GABAergic interneurons functionally integrated with glutamatergic neurons to form a microphysiological system. Single cell analyses revealed that assembloids obtained by fusing patterned dorsal and ventral forebrain organoids have proper transcriptional profiles corresponding to those identified in the early developing dorsal and ventral forebrain (Birey et al. 2017; Xiang et al. 2017; Giandomenico et al. 2019; Yoon et al. 2019).

To study the human cortico-striatal circuitry that regulates motivated behaviors, human PSCs were converted into region-specific brain organoids that resembled the developing human striatum and contained electrically active medium spiny neurons. Striatal organoids were then fused with cerebral cortical organoids in three-dimensional cultures to form cortico-striatal assembloids (Miura et al. 2020). Using viral tracing and functional assays, it was shown that cortical neurons sent axonal projections into striatal organoids and formed functional synaptic connections. Moreover, striatal medium spiny neurons matured electrophysiologically and displayed calcium activity after optogenetic stimulation of cortical neurons. Similarly, functional human cortico-motor assembloids were generated by fusing cortical organoids to organoids resembling the hindbrain/spinal cord that were further assembled with human skeletal muscle spheroids to yield 3D cortico-motor assembloids (Andersen et al. 2020). Using rabies virus synaptic tracing, calcium imaging, and patch-clamp recordings, it was shown that corticofugal neurons project and connect with spinal spheroids, while spinal-derived motor neurons connect with muscle. These systems highlight the remarkable self-assembly potential of 3D cultures to form functional circuits that could help us understand human brain development and disease.

\section{Disease modeling with brain organoids}

To date, a number of important studies have modeled neurodevelopmental disorders, including microcephaly (Lancaster et al. 2013), lissencephaly (Bershteyn et al. 2017; lefremova et al. 2017), autism spectrum disorders (Mariani et al. 2015), schizophrenia (Stachowiak et al. 2017) and zika virus infection (Cugola et al. 2016; Qian et al. 2016) in human organoids. Relevant disease 
phenotypes and, in some cases, associated disease mechanisms, have been uncovered. Using a forebrain assembloid system resulting from fusion of spheroids with dorsal and ventral forebrain identities, Birey et al demonstrated that in Timothy syndrome, a neurodevelopmental disorder caused by mutations in the CaV1.2 calcium channel, GABAergic interneurons display abnormal migratory behavior (Birey et al. 2017). Remarkably, identification and correction of mechanisms underlying a type of inherited blindness, in which photoreceptors are sensitive to an intronic mutation in the cilia-related gene CEP290 that causes missplicing and premature termination, was achieved in human PSC-derived optic cups. Treatment with an antisense morpholino effectively blocked aberrant splicing and restored expression of full-length CEP290, restoring normal cilia-based protein trafficking (Parfitt et al. 2016). Three-dimensional organoid culture models also offer innovative possibilities for modelling human brain tumorigenesis. In this respect, Bian et al established a 3D in vitro model, termed neoplastic cerebral organoid, in which brain tumorigenesis was recapitulated by introducing oncogenic mutations into cerebral organoids via transposon- and CRISPR/Cas9-mediated mutagenesis (Bian et al. 2018). Similarly, Ogawa et al developed a cancer model of gliomas in human cerebral organoids that allows direct observation of tumor initiation as well as continuous microscopic observations (Ogawa et al. 2018). These models should provide complementary means to existing basic and preclinical models for studying brain tumor biology.

As with two-dimensional cultures, the idea of using 3D brain organoids to study neurodegenerative diseases was initially met with skepticism. However, the few models that have been developed so far indicate that it is possible to recapitulate disease phenotypes, particularly for early onset but also for age-related pathologies. Thus, a successful 3D model was developed for Alzheimer's disease, the most common type of dementia, displaying disease hallmarks, such as deposition of extracellular amyloid- $\beta$ plaques and the formation of intracellular neurofibrillary tangles composed of aggregated hyperphosphorylated tau. This model was produced by overexpression of human beta-amyloid precursor protein and presenilin 1 with FAD mutations in human neural stem cells (Choi et al. 2014). A more refined three-dimensional human triculture model was developed for Alzheimer's disease, incorporating neurons, astrocytes, and microglia in a 3D microfluidic platform (Park et al. 2018). Apart from beta-amyloid aggregation and phosphorylated tau accumulation, this model also presented neuroinflammation, an essential pathological manifestation in Alzheimer's disease. In particular, the model mirrored microglial recruitment, neurotoxic activities such as axonal cleavage, and nitric oxide release damaging neurons and astrocytes. These observations were complemented by another study, demonstrating that APOE4 exacerbates synapse loss and neurodegeneration in PSC-derived cerebral organoids derived from Alzheimer's disease patients (Zhao et al. 2020). Transcriptomics profiling revealed that the cerebral organoids derived from these patients are associated with an enhancement of stress granules and disrupted RNA metabolism.

Two recent studies highlighted the generation of midbrain organoids in patients bearing the LRRK2 G2019S mutation associated with Parkinson's disease. In both cases, the organoids could recapitulate disease-relevant phenotypes. In the first study, analysis of the protein-protein interaction network in mutant organoids revealed
A

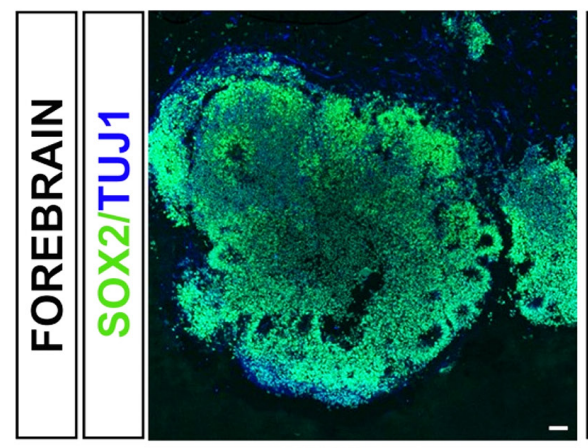

B

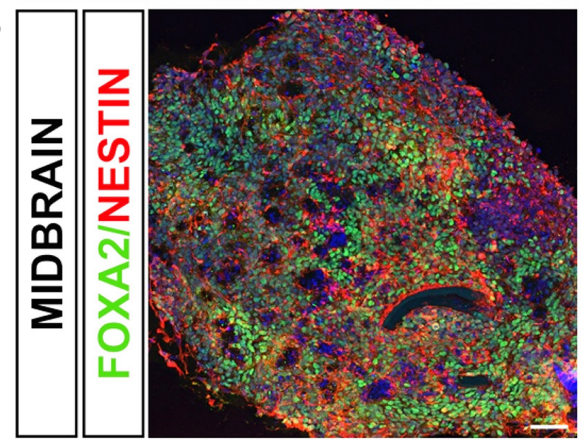

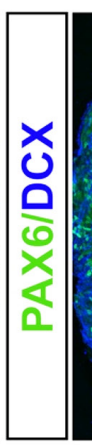
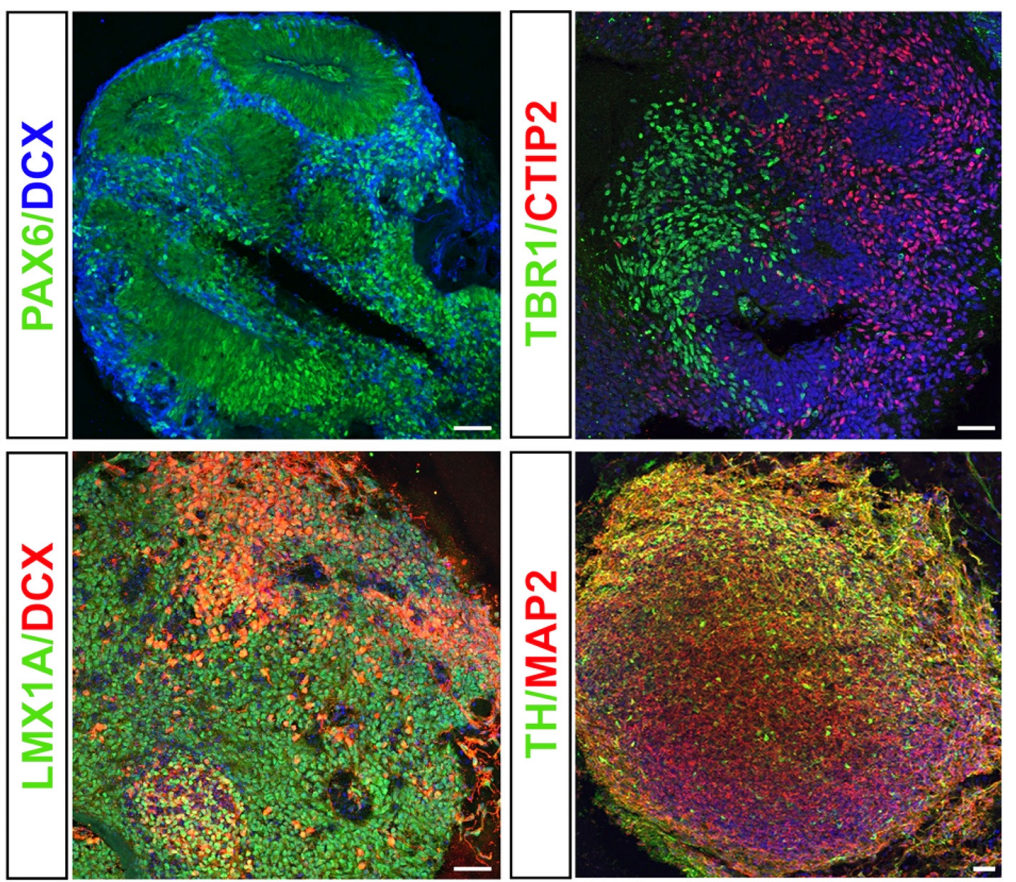

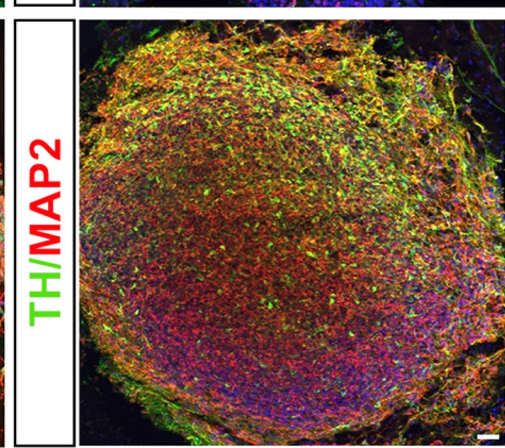

Fig. 2. Forebrain and midbrain PSC-derived organoids. (A) Immunocytochemical characterization of forebrain organoids at 30 days in vitro confirmed the existence of SOX2+ and PAX6+ neural progenitors, doublecortin (DCX)+ early neuroblasts, TUJ1+ neurons and TBR1+ and CTIP2+ deep-layer early cortical neurons. Scale bar, $50 \mu \mathrm{m}$. (B) Midbrain organoids exhibited spatially organized groups of NESTIN+ neural progenitors, FOXA2+ midbrain floor plate progenitors and LMX1A+ early midbrain dopaminergic progenitors at 30 days in vitro; MAP2+ neurons and tyrosine hydroxylase (TH)+ dopaminergic neurons are evident at 60 days in vitro. Scale bar, $50 \mu \mathrm{m}$. 
that TXNIP, a thiol-oxidoreductase, is functionally important in the development of LRRK2 pathology (Kim et al. 2019). In the second report, the floor plate marker FOXA2, required for dopaminergic neuron generation, was increased in patient organoids, surprisingly suggesting a neurodevelopmental defect (Smits et al. 2019).

Parkinson's disease and related synucleinopathies are a group of neurodegenerative disorders strongly associated with alphasynuclein pathology. The best-characterized mutation is G209A in the alpha-synuclein gene SNCA, resulting in the pathological p.A53T-alpha-synuclein protein. We have previously established a 2D PSC-based model from patients bearing the p.A53T- alphasynuclein mutation that simulates disease-relevant phenotypes, including protein aggregates, compromised neuritic growth, axonal pathology and reduced synaptic connectivity (Kouroupi et al. 2017). To elucidate unexplored aspects of p.A53T pathology in an environment resembling more closely the in vivo situation, we recently generated forebrain and midbrain PSC-derived organoids (Fig. 2). Forebrain organoids at 30 days in vitro consisted of radially aligned neural progenitor cells and early cortical neurons. In particular, immunocytochemical characterization confirmed the existence of PAX6+ and SOX2+ neural progenitors, HOPX+ outer radial glia, DCX+ early neuroblasts, and CTIP2+ deep layer early cortical neurons. On the other hand, midbrain organoids maintained for up to 60 days in vitro exhibited spatially organized groups of FOXA2+ midbrain floor plate progenitors, LMX1A+ early and NURR1+ late midbrain dopaminergic progenitors, as well as tyrosine hydroxylase $(\mathrm{TH})+$ dopamine neurons. Detailed characterization for neuronal and astroglial differentiation in p.A53T organoids vis-à-vis isogenic gene-corrected or healthy controls is in progress, to explore alpha-synuclein-relevant pathology and assess therapeutic interventions.

\section{Current limitations and future perspectives}

The last decade has witnessed major progress in PSC technologies for modeling human organogenesis and disease. In particular, the appearance of three-dimensional systems of increasing complexity, mimicking the brain microenvironment, represents a leap forward in terms of modeling neurological disease, as well as for developmental and evolutionary studies. Nevertheless, there are still limitations to overcome. An important drawback is the insufficient oxygen and nutrient diffusion within organoids that results in limited maturation and the formation of a necrotic core. Another serious shortcoming is the high degree of heterogeneity in efficiency of differentiation, morphology and size across different batches, which is higher when self-patterned protocols are used. Inclusion of exogenous patterning factors and more controlled conditions should contribute towards the desired outcome. To overcome the lack of vasculature, brain organoids have been transplanted to rodent hosts to achieve vascularization in vivo (Mansour et al. 2018). There have also been attempts to reproduce blood vessels in vitro, including co-culture of endothelial and mesenchymal stem cells with PSC-derived organoids. However, further optimization is necessary. The use of supporting matrices or microfluidic devices and other brain-on-chip technologies may be useful in this respect and open the way for more homogenous and reproducible cultures.

In conclusion, stem cell technologies have contributed in an unprecedented fashion to the study of brain development and disease. Brain organoids, at the interphase between in vitro and in vivo, have opened up prospects for numerous human studies that would otherwise have been impossible. PSC-derived human brain organoids display remarkably organized architecture that mimics neurogenesis in a temporally and spatially regulated fashion, recapitulating embryonic brain development. Such systems have the potential to increase understanding of evolutionary aspects and uncover human-specific traits. In combination with enabling technologies, such as genome-editing, advanced imaging, automated drug screening and artificial intelligence approaches, brain organoids have great potential to yield novel biological insights into brain pathophysiology.

\section{Acknowledgments}

The authors thank all members of the Laboratory of Cellular and Molecular Neurobiology - Stem Cells for helpful discussions. Our work is supported by funding to R.M. by: the Hellenic Foundation for Research and Innovation (H.F.R.I.) under the "1st Call for H.F.R.I. Research Projects to support Faculty members and Researchers and the procurement of high-cost research equipment" (Project Number: 1019); the Hellenic General Secretariat for Research and Innovation (G.S.R.I.) Flagship Action for Neurodegenerative Diseases on the basis of Personalized Medicine

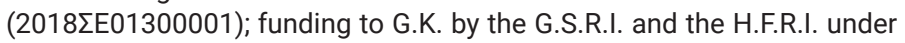
the "1st Call for H.F.R.I. Research Projects to support Postdoctoral Researchers" (PARKINSynapse 899); a Stavros Niarchos Foundation Grant to the H.P.I., as part of the Foundation's initiative to support the Greek research center ecosystem.

\section{References}

ABUD E. M., RAMIREZ R. N., MARTINEZ E. S., HEALY L. M., NGUYEN C. H.H., NEWMAN S. A., YEROMIN A. V., SCARFONE V. M., MARSH S. E., FIMBRES C., CARAWAY C. A., FOTE G. M., MADANY A. M., AGRAWAL A., KAYED R., GYLYS K. H., CAHALAN M. D., CUMMINGS B. J., ANTEL J. P., MORTAZAVI A., CARSON M. J., POON W. W., BLURTON-JONES M. (2017). iPSC-Derived Human Microglialike Cells to Study Neurological Diseases. Neuron 94: 278-293.e9. https://doi. org/10.1016/j.neuron.2017.03.042

ADLER A. F., CARDOSO T., NOLBRANT S., MATTSSON B., HOBAN D. B., JARL U., WAHLESTEDT J. N., GREALISH S., BJÖRKLUND A., PARMAR M. (2019). hESC-Derived Dopaminergic Transplants Integrate into Basal Ganglia Circuitry in a Preclinical Model of Parkinson's Disease. Cell Reports 28:3462-3473.e5. https:// doi.org/10.1016/j.celrep.2019.08.058

ANDERSEN J., REVAH O., MIURA Y., THOM N., AMIN N. D., KELLEY K. W., SINGH M., CHEN X., THETE M. V., WALCZAK E. M., VOGEL H., FAN H. C., PAŞCA S. P. (2020). Generation of Functional Human 3D Cortico-Motor Assembloids. Cell 183: 1913-1929.e26. https://doi.org/10.1016/j.cell.2020.11.017

ANTONIOUN.,PRODROMIDOUK., KOUROUPIG.,BOUMPOUREKAI.,SAMIOTAKIM., PANAYOTOU G., XILOURI M., KLOUKINA I., STEFANIS L., GRAILHE R., TAOUFIK E., MATSAS R. (2022). High content screening and proteomic analysis identify a kinase inhibitor that rescues pathological phenotypes in a patient-derived model of Parkinson's disease. npj Parkinson's Disease 8: 15. https://doi.org/10.1038/ s41531-022-00278-y

BALEZ R., STEINER N., ENGEL M., MUÑOZ S. S., LUM J. S., WU Y., WANG D., VALLOTTON P., SACHDEV P., O'CONNOR M., SIDHU K., MÜNCH G., OOI L. (2016). Neuroprotective effects of apigenin against inflammation, neuronal excitability and apoptosis in an induced pluripotent stem cell model of Alzheimer's disease. Scientific Reports 6: 31450. https://doi.org/10.1038/srep31450

BARBAR L., JAIN T., ZIMMER M., KRUGLIKOVI., SADICK J. S., WANG M., KALPANA K., ROSE I. V.L., BURSTEIN S. R., RUSIELEWICZ T., NIJSURE M., GUTTENPLAN K. A., DI DOMENICO A., CROFT G., ZHANG B., NOBUTA H., HÉBERT J. M., LIDDELOW S. A., FOSSATI V. (2020). CD49f Is a Novel Marker of Functional and Reactive Human iPSC-Derived Astrocytes. Neuron 107: 436-453.e12. https://doi. org/10.1016/j.neuron.2020.05.014

BARKER R. A., PARMAR M., STUDER L., TAKAHASHI J. (2017). Human Trials of Stem Cell-Derived Dopamine Neurons for Parkinson's Disease: Dawn of a New Era. Cell Stem Cell 21: 569-573. https://doi.org/10.1016/j.stem.2017.09.014 
BENNER E. J., LUCIANO D., JO R., ABDI K., PAEZ-GONZALEZ P., SHENG H., WARNER D. S., LIU C., EROGLU C., KUO C. T. (2013). Protective astrogenesis from the SVZ niche after injury is controlled by Notch modulator Thbs4. Nature 497: 369-373. https://doi.org/10.1038/nature12069

BERSHTEYN M., NOWAKOWSKI T. J., POLLEN A. A., DI LULLO E., NENE A., WYNSHAW-BORIS A., KRIEGSTEIN A. R. (2017). Human iPSC-Derived Cerebral Organoids Model Cellular Features of Lissencephaly and Reveal Prolonged Mitosis of Outer Radial Glia. Cell Stem Cell 20: 435-449.e4. https://doi.org/10.1016/j. stem.2016.12.007

BIAN S., REPIC M., GUO Z., KAVIRAYANI A., BURKARD T., BAGLEY J. A., KRAUDITSCH C., KNOBLICH J. A. (2018). Genetically engineered cerebral organoids model brain tumor formation. Nature Methods 15: 631-639. https://doi. org/10.1038/s41592-018-0070-7

BIREY F., ANDERSEN J., MAKINSON C. D., ISLAM S., WEI W., HUBER N., FAN H. C., METZLER K. R. C., PANAGIOTAKOS G., THOM N., O'ROURKE N. A., STEINMETZ L. M., BERNSTEIN J. A., HALLMAYER J., HUGUENARD J. R., PASSCA S. P. (2017). Assembly of functionally integrated human forebrain spheroids. Nature 545: 54-59. https://doi.org/10.1038/nature22330

BJÖRKLUND A., LINDVALL O. (2000). Cell replacement therapies for central nervous system disorders. Nature Neuroscience 3: 537-544. https://doi. org/10.1038/75705

CAKIR B., XIANG Y., TANAKA Y., KURAL M. H., PARENT M., KANG Y.J., CHAPETON K., PATTERSON B., YUAN Y., HE C.S., RAREDON M. S. B., DENGELEGI J., KIM K.Y., SUN P., ZHONG M., LEE S., PATRA P., HYDER F., NIKLASON L. E., LEE S.H., YOON Y.S., PARK I.H. (2019). Engineering of human brain organoids with a functional vascular-like system. Nature Methods 16: 1169-1175. https://doi. org/10.1038/s41592-019-0586-5

CAMP J. G., BADSHA F., FLORIO M., KANTON S., GERBERT., WILSCH-BRÄUNINGER M., LEWITUS E., SYKES A., HEVERS W., LANCASTER M., KNOBLICH J. A., LACHMANN R., PÄÄBO S., HUTTNER W. B., TREUTLEIN B. (2015). Human cerebral organoids recapitulate gene expression programs of fetal neocortex development. Proceedings of the National Academy of Sciences 112: 1567215677. https://doi.org/10.1073/pnas. 1520760112

CHAMBERS S. M., FASANO C. A., PAPAPETROU E. P., TOMISHIMA M., SADELAIN M., STUDER L. (2009). Highly efficient neural conversion of human ES and iPS cells by dual inhibition of SMAD signaling. Nature Biotechnology 27: 275-280. https://doi.org/10.1038/nbt.1529

CHOI S. H., KIM Y. H., HEBISCH M., SLIWINSKI C., LEE S., D'AVANZO C., CHEN H., HOOLI B., ASSELIN C., MUFFAT J., KLEE J. B., ZHANG C., WAINGER B. J., PEITZ M., KOVACS D. M., WOOLF C. J., WAGNER S. L., TANZI R. E., KIM D. Y. (2014). A three-dimensional human neural cell culture model of Alzheimer's disease. Nature 515: 274-278. https://doi.org/10.1038/nature13800

CHUNG C. Y., KHURANA V., AULUCK P. K., TARDIFF D. F., MAZZULLI J. R., SOLDNER F., BARU V., LOU Y., FREYZON Y., CHO S., MUNGENAST A. E., MUFFAT J., MITALIPOVA M., PLUTH M. D., JUI N. T., SCHÜLE B., LIPPARD S. J., TSAI L.H., KRAINC D., BUCHWALD S. L., JAENISCH R., LINDQUIST S. (2013). Identification and Rescue of a-Synuclein Toxicity in Parkinson Patient-Derived Neurons. Science 342: 983-987. https://doi.org/10.1126/science.1245296

CONSORTIUM H. D. I. (2012). Induced Pluripotent Stem Cells from Patients with Huntington's Disease Show CAG-Repeat-Expansion-Associated Phenotypes. Cell Stem Cell 11: 264-278. https://doi.org/10.1016/j.stem.2012.04.027

CUGOLA F. R., FERNANDES I. R., RUSSO F. B., FREITAS B. C., DIAS J. L. M., GUIMARÃES K. P., BENAZZATO C., ALMEIDA N., PIGNATARI G. C., ROMERO S., POLONIO C. M., CUNHA I., FREITAS C. L., BRANDÃO W. N., ROSSATO C., ANDRADE D. G., FARIA D. P., GARCEZ A. T., BUCHPIGEL C. A., BRACONI C. T., MENDES E., SALL A. A., ZANOTTO P. M. A., PERON J. P. S., MUOTRI A. R., BELTRÃO-BRAGA P. C. B. (2016). The Brazilian Zika virus strain causes birth defects in experimental models. Nature 534: 267-271. https://doi.org/10.1038/ nature18296

DI DOMENICO A., CAROLA G., CALATAYUD C., PONS-ESPINAL M., MUÑOZ J. P., RICHAUD-PATIN Y., FERNANDEZ-CARASA I., GUT M., FAELLA A., PARAMESWARAN J., SORIANO J., FERRERI.,TOLOSA E.,ZORZANO A., CUERVO A. M., RAYA A., CONSIGLIO A. (2019). Patient-Specific iPSC-Derived Astrocytes Contribute to Non-Cell-Autonomous Neurodegeneration in Parkinson's Disease. Stem Cell Reports 12: 213-229. https://doi.org/10.1016/j.stemcr.2018.12.011

DOETSCH F., CAILLÉ I., LIM D. A., GARCÍA-VERDUGO J. M., ALVAREZ-BUYLLA A. (1999). Subventricular Zone Astrocytes Are Neural Stem Cells in the Adult Mammalian Brain. Cell 97: 703-716. https://doi.org/10.1016/S0092-8674(00)80783-7
DUAN L., BHATTACHARYYA B. J., BELMADANI A., PAN L., MILLER R. J., KESSLER J. A. (2014). Stem cell derived basal forebrain cholinergic neurons from Alzheimer's disease patients are more susceptible to cell death. Molecular Neurodegeneration 9: 3. https://doi.org/10.1186/1750-1326-9-3

EHRLICH M., MOZAFARI S., GLATZA M., STAROST L., VELYCHKO S., HALLMANN A.L., CUI Q.L., SCHAMBACH A., KIM K.P., BACHELIN C., MARTEYN A., HARGUS G., JOHNSON R. M., ANTEL J., STERNECKERT J., ZAEHRES H., SCHÖLER H. R., BARON-VAN EVERCOOREN A., KUHLMANN T. (2017). Rapid and efficient generation of oligodendrocytes from human induced pluripotent stem cells using transcription factors. Proceedings of the National Academy of Sciences 114: E2243-E2252. https://doi.org/10.1073/pnas.1614412114

EIRAKU M., TAKATA N., ISHIBASHI H., KAWADA M., SAKAKURA E., OKUDA S., SEKIGUCHI K., ADACHI T., SASAI Y. (2011). Self-organizing optic-cup morphogenesis in three-dimensional culture. Nature 472: 51-56. https://doi.org/10.1038/ nature09941

EIRAKU M., WATANABE K., MATSUO-TAKASAKI M., KAWADA M., YONEMURA S., MATSUMURA M., WATAYA T., NISHIYAMA A., MUGURUMA K., SASAI Y. (2008). Self-Organized Formation of Polarized Cortical Tissues from ESCs and Its Active Manipulation by Extrinsic Signals. Cell Stem Cell 3: 519-532. https:// doi.org/10.1016/j.stem.2008.09.002

ELKABETZ Y., PANAGIOTAKOS G., AL SHAMY G., SOCCI N. D., TABAR V., STUDER L. (2008). Human ES cell-derived neural rosettes reveal a functionally distinct early neural stem cell stage. Genes \& Development 22: 152-165. https://doi. org/10.1101/gad. 1616208

ESPUNY-CAMACHO I., MICHELSEN K. A., GALL D., LINARO D., HASCHE A., BONNEFONT J., BALI C., ORDUZ D., BILHEU A., HERPOEL A., LAMBERT N., GASPARD N., PÉRON S., SCHIFFMANN S. N., GIUGLIANO M., GAILLARD A., VANDERHAEGHEN P. (2013). Pyramidal Neurons Derived from Human Pluripotent Stem Cells Integrate Efficiently into Mouse Brain Circuits In Vivo. Neuron 77: 440-456. https://doi.org/10.1016/j.neuron.2012.12.011

ESPUNY-CAMACHOI.,MICHELSEN K. A., LINARO D., BILHEU A., ACOSTA-VERDUGO S., HERPOEL A., GIUGLIANO M., GAILLARD A., VANDERHAEGHEN P. (2018). Human Pluripotent Stem-Cell-Derived Cortical Neurons Integrate Functionally into the Lesioned Adult Murine Visual Cortex in an Area-Specific Way. Cell Reports 23: 2732-2743. https://doi.org/10.1016/j.celrep.2018.04.094

GASPARD N., BOUSCHET T., HOUREZ R., DIMIDSCHSTEIN J., NAEIJE G., VAN DEN AMEELE J., ESPUNY-CAMACHO I., HERPOEL A., PASSANTE L., SCHIFFMANN S. N., GAILLARD A., VANDERHAEGHEN P. (2008). An intrinsic mechanism of corticogenesis from embryonic stem cells. Nature 455: 351-357. https://doi. org/10.1038/nature07287

GIANDOMENICO S. L., MIERAU S. B., GIBBONS G. M., WENGER L. M. D., MASULLO L., SIT T., SUTCLIFFE M., BOULANGER J., TRIPODI M., DERIVERY E., PAULSEN O., LAKATOS A., LANCASTER M. A. (2019). Cerebral organoids at the air-liquid interface generate diverse nerve tracts with functional output. Nature Neuroscience 22: 669-679. https://doi.org/10.1038/s41593-019-0350-2

HASSELMANN J., BLURTON-JONES M. (2020). Human iPSC-derived microglia: A growing toolset to study the brain's innate immune cells. Glia 68: 721-739. https:// doi.org/10.1002/glia.23781

HERCULANO-HOUZEL S., COLLINS C. E., WONG P., KAAS J. H. (2007). Cellular scaling rules for primate brains. Proceedings of the National Academy of Sciences 104: 3562-3567. https://doi.org/10.1073/pnas.0611396104

HERCULANO-HOUZEL S., MOTA B., LENT R. (2006). Cellular scaling rules for rodent brains. Proceedings of the National Academy of Sciences 103: 12138-12143. https://doi.org/10.1073/pnas.0604911103

IEFREMOVA V., MANIKAKIS G., KREFFT O., JABALI A., WEYNANS K., WILKENS R., MARSONER F., BRÄNDL B., MÜLLER F.J., KOCH P., LADEWIG J. (2017). An Organoid-Based Model of Cortical Development Identifies Non-Cell-Autonomous Defects in Wnt Signaling Contributing to Miller-Dieker Syndrome. Cell Reports 19: 50-59. https://doi.org/10.1016/j.celrep.2017.03.047

JO J., XIAO Y., SUN A. X., CUKUROGLU E., TRAN H.D., GÖKE J., TAN Z. Y., SAW T. Y., TAN C.P., LOKMAN H., LEE Y., KIM D., KO H. S., KIM S.O., PARK J. H., CHO N.J., HYDE T. M., KLEINMAN J. E., SHIN J. H., WEINBERGER D. R., TAN E. K., JE H. S., NG H.H. (2016). Midbrain-like Organoids from Human Pluripotent Stem Cells Contain Functional Dopaminergic and Neuromelanin-Producing Neurons. Cell Stem Cell 19: 248-257. https://doi.org/10.1016/j.stem.2016.07.005

JONES V. C., ATKINSON-DELL R., VERKHRATSKY A., MOHAMET L. (2017). Aberrant iPSC-derived human astrocytes in Alzheimer's disease. Cell Death \& Disease 8: e2696-e2696. https://doi.org/10.1038/cddis.2017.89 
KADOSHIMA T., SAKAGUCHI H., EIRAKU M. (2017). Generation of Various Telencephalic Regions from Human Embryonic Stem Cells in Three-Dimensional Culture. In Organ Regeneration (Ed. T. Takashi). Methods in Molecular Biology, Vol. 1597. Springer New York, New York, NY, pp. 1-16. https://doi.org/10.1007/9781-4939-6949-4_1

KALTEZIOTI V., KOUROUPI G., OIKONOMAKI M., MANTOUVALOU E., STERGIOPOULOS A., CHARONIS A., ROHRER H., MATSAS R., POLITIS P. K. (2010). Prox1 Regulates the Notch1-Mediated Inhibition of Neurogenesis. PLoS Biology 8: e1000565. https://doi.org/10.1371/journal.pbio.1000565

KANTON S., BOYLE M. J., HE Z., SANTEL M., WEIGERT A., SANCHÍS-CALLEJA F., GUIJARRO P., SIDOW L., FLECK J. S., HAN D., QIAN Z., HEIDE M., HUTTNER W. B., KHAITOVICH P., PÄÄBO S., TREUTLEIN B., CAMP J. G. (2019). Organoid single-cell genomic atlas uncovers human-specific features of brain development. Nature 574: 418-422. https://doi.org/10.1038/s41586-019-1654-9

KATSIMPARDI L., GAITANOU M., MALNOU C. E., LLEDO P.M., CHARNEAU P., MATSAS R., THOMAIDOU D. (2008). BM88/Cend1 Expression Levels Are Critical for Proliferation and Differentiation of Subventricular Zone-Derived Neural Precursor Cells. Stem Cells 26: 1796-1807. https://doi.org/10.1634/stemcells.2007-0921

KEMPERMANN G., GAGE F. H., AIGNER L., SONG H., CURTIS M. A., THURET S., KUHN H. G., JESSBERGER S., FRANKLAND P. W., CAMERON H. A., GOULD E., HEN R., ABROUS D. N., TONI N., SCHINDER A. F., ZHAO X., LUCASSEN P. J., FRISÉN J. (2018). Human Adult Neurogenesis: Evidence and Remaining Questions. Cell Stem Cell 23: 25-30. https://doi.org/10.1016/j.stem.2018.04.004

KEMPERMANN G., JESSBERGER S., STEINER B., KRONENBERG G. (2004). Milestones of neuronal development in the adult hippocampus. Trends in Neurosciences 27: 447-452. https://doi.org/10.1016/j.tins.2004.05.013

KESKIN I., FORSGREN E., LEHMANN M., ANDERSEN P. M., BRÄNNSTRÖM T., LANGE D. J., SYNOFZIK M., NORDSTRÖM U., ZETTERSTRÖM P., MARKLUND S. L., GILTHORPE J. D. (2019). The molecular pathogenesis of superoxide dismutase 1-linked ALS is promoted by low oxygen tension. Acta neuropathologica 138: 85-101. https://doi.org/10.1007/s00401-019-01986-1

KIKUCHI T., MORIZANE A., DOI D., MAGOTANI H., ONOE H., HAYASHI T., MIZUMA H., TAKARA S., TAKAHASHI R., INOUE H., MORITA S., YAMAMOTO M., OKITA K., NAKAGAWA M., PARMAR M., TAKAHASHI J. (2017). Human iPS cell-derived dopaminergic neurons function in a primate Parkinson's disease model. Nature 548: 592-596. https://doi.org/10.1038/nature23664

KIM H., PARK H. J., CHOI H., CHANG Y., PARK H., SHIN J., KIM J., LENGNER C. J., LEE Y. K., KIM J. (2019). Modeling G2019S-LRRK2 Sporadic Parkinson's Disease in 3D Midbrain Organoids. Stem Cell Reports 12: 518-531. https://doi.org/10.1016/j. stemcr.2019.01.020

KIM J., KOO B.K., KNOBLICH J. A. (2020). Human organoids: model systems for human biology and medicine. Nature Reviews Molecular Cell Biology 21: 571-584. https://doi.org/10.1038/s41580-020-0259-3

KONDOT., IMAMURA K., FUNAYAMAM., TSUKITAK., MIYAKEM., OHTAA., WOLTJEN K., NAKAGAWA M., ASADA T., ARAIT., KAWAKATSUS., IZUMIY., KAJI R., IWATA N., INOUE H. (2017). iPSC-Based Compound Screening and In Vitro Trials Identify a Synergistic Anti-amyloid $\beta$ Combination for Alzheimer's Disease. Cell Reports 21: 2304-2312. https://doi.org/10.1016/j.celrep.2017.10.109

KOUROUPI G., ANTONIOU N., PRODROMIDOU K., TAOUFIK E., MATSAS R. (2020). Patient-Derived Induced Pluripotent Stem Cell-Based Models in Parkinson's Disease for Drug Identification. International Journal of Molecular Sciences 21: 7113. https://doi.org/10.3390/ijms21197113

KOUROUPIG., TAOUFIKE., VLACHOSI.S., TSIORAS K., ANTONIOU N., PAPASTEFANAKI F., CHRONI-TZARTOU D., WRASIDLO W., BOHL D., STELLAS D., POLITIS P. K., VEKRELLIS K., PAPADIMITRIOU D., STEFANIS L., BREGESTOVSKI P., HATZIGEORGIOU A. G., MASLIAH E., MATSAS R. (2017). Defective synaptic connectivity and axonal neuropathology in a human iPSC-based model of familial Parkinson's disease. Proceedings of the National Academy of Sciences 114: E3679-E3688. https://doi.org/10.1073/pnas.1617259114

KOUTSOUDAKI P. N., PAPASTEFANAKI F., STAMATAKIS A., KOUROUPI G., XINGI E., STYLIANOPOULOU F., MATSAS R. (2016). Neural stem/progenitor cells differentiate into oligodendrocytes, reduce inflammation, and ameliorate learning deficits after transplantation in a mouse model of traumatic brain injury. Glia 64 : 763-779. https://doi.org/10.1002/glia.22959

KRIEGSTEIN A., ALVAREZ-BUYLLA A. (2009). The Glial Nature of Embryonic and Adult Neural Stem Cells. Annual Review of Neuroscience 32: 149-184. https://doi. org/10.1146/annurev.neuro.051508.135600
KRIKS S., SHIM J.W., PIAO J., GANATY.M., WAKEMAN D. R., XIEZ., CARRILLO-REID L., AUYEUNG G., ANTONACCI C., BUCH A., YANG L., BEAL M. F., SURMEIER D. J., KORDOWER J. H., TABAR V., STUDER L. (2011). Dopamine neurons derived from human ES cells efficiently engraft in animal models of Parkinson's disease. Nature 480: 547-551. https://doi.org/10.1038/nature10648

LANCASTERM. A., RENNERM., MARTIN C.A., WENZEL D., BICKNELLL. S., HURLES M. E., HOMFRAY T., PENNINGER J. M., JACKSON A. P., KNOBLICH J. A. (2013). Cerebral organoids model human brain development and microcephaly. Nature 501: 373-379. https://doi.org/10.1038/nature12517

LEBAIL R., BONAFINA A., ESPUNY-CAMACHO I., NGUYEN L. (2021). Learning about cell lineage, cellular diversity and evolution of the human brain through stem cell models. Current Opinion in Neurobiology 66: 166-177. https://doi.org/10.1016/j. conb.2020.10.018

LI W., ENGLUND E., WIDNER H., MATTSSON B., VAN WESTEN D., LÄTT J., REHNCRONA S., BRUNDIN P., BJÖRKLUND A., LINDVALL O., LI J.Y. (2016). Extensive graft-derived dopaminergic innervation is maintained 24 years after transplantation in the degenerating parkinsonian brain. Proceedings of the National Academy of Sciences 113:6544-6549. https://doi.org/10.1073/pnas.1605245113

LI Z., TYLER W. A., ZELDICH E., SANTPERE BARÓ G., OKAMOTO M., GAO T., LI M., SESTAN N., HAYDAR T. F. (2020). Transcriptional priming as a conserved mechanism of lineage diversification in the developing mouse and human neocortex. Science Advances 6: eabd2068. https://doi.org/10.1126/sciadv.abd2068

LIN Y.T., SEO J., GAO F., FELDMAN H. M., WEN H.L., PENNEY J., CAM H. P. GJONESKA E., RAJA W. K., CHENG J., RUEDA R., KRITSKIY O., ABDURROB F., PENG Z., MILO B., YU C. J., ELMSAOURI S., DEY D., KO T., YANKNER B. A., TSAI L.H. (2018). APOE4 Causes Widespread Molecular and Cellular Alterations Associated with Alzheimer's Disease Phenotypes in Human iPSC-Derived Brain Cell Types. Neuron 98: 1141-1154.e7. https://doi.org/10.1016/j.neuron.2018.05.008

LINDVALL O., SAWLE G., WIDNER H., ROTHWELL J. C., BJÖRKLUND A., BROOKS D., BRUNDIN P., FRACKOWIAK R., MARSDEN C. D., ODIN P., REHNCRONA S. (1994). Evidence for long-term survival and function of dopaminergic grafts in progressive Parkinson's disease. Annals of Neurology 35: 172-180. https://doi. org/10.1002/ana.410350208

LODATO S., ARLOTTA P. (2015). Generating Neuronal Diversity in the Mammalian Cerebral Cortex. Annual Review of Cell and Developmental Biology 31: 699-720. https://doi.org/10.1146/annurev-cellbio-100814-125353

LUI J. H., HANSEN D. V., KRIEGSTEIN A. R. (2011). Development and Evolution of the Human Neocortex. Cell 146:18-36. https://doi.org/10.1016/j.cell.2011.06.030

MANSOUR A. A.F., GONÇALVES J. T., BLOYD C. W., LI H., FERNANDES S., QUANG D., JOHNSTON S., PARYLAK S. L., JIN X., GAGE F. H. (2018). An in vivo model of functional and vascularized human brain organoids. Nature Biotechnology 36 : 432-441. https://doi.org/10.1038/nbt.4127

MARIANI J., COPPOLA G., ZHANG P., ABYZOV A., PROVINI L., TOMASINI L. AMENDUNI M., SZEKELY A., PALEJEV D., WILSON M., GERSTEIN M., GRIGORENKO E. L., CHAWARSKA K., PELPHREY K. A., HOWE J. R., VACCARINO F. M (2015). FOXG1-Dependent Dysregulation of GABA/Glutamate Neuron Differentiation in Autism Spectrum Disorders. Cell 162: 375-390. https://doi.org/10.1016/j. cell.2015.06.034

MARTON R. M., MIURA Y., SLOAN S. A., LI Q., REVAH O., LEVY R. J., HUGUENARD J. R., PAȘCA S. P. (2019). Differentiation and maturation of oligodendrocytes in human three-dimensional neural cultures. Nature Neuroscience 22: 484-491. https://doi.org/10.1038/s41593-018-0316-9

MERTENS J., STÜBER K., WUNDERLICH P., LADEWIG J., KESAVAN J. C., VANDENBERGHE R., VANDENBULCKE M., VAN DAMME P., WALTER J., BRÜSTLE O., KOCH P. (2013). APP Processing in Human Pluripotent Stem Cell-Derived Neurons Is Resistant to NSAID-Based $y$-Secretase Modulation. Stem Cell Reports 1: 491-498. https://doi.org/10.1016/j.stemcr.2013.10.011

MILTIADOUS P., KOUROUPI G., STAMATAKIS A., KOUTSOUDAKI P. N., MATSAS R., STYLIANOPOULOU F. (2013). Subventricular Zone-Derived Neural Stem Cell Grafts Protect Against Hippocampal Degeneration and Restore Cognitive Function in the Mouse Following Intrahippocampal Kainic Acid Administration. STEM CELLSTranslationalMedicine 2: 185-198. https://doi.org/10.5966/sctm.2012-0074

MIURA Y., LI M.Y., BIREY F., IKEDA K., REVAH O., THETE M. V., PARK J.Y., PUNO A., LEE S. H., PORTEUS M. H., PAȘCA S. P. (2020). Generation of human striatal organoids and cortico-striatal assembloids from human pluripotent stem cells. Nature Biotechnology 38: 1421-1430. https://doi.org/10.1038/ s41587-020-00763-w 
MUGURUMA K., NISHIYAMA A., KAWAKAMI H., HASHIMOTO K., SASAI Y. (2015). Self-Organization of Polarized Cerebellar Tissue in 3D Culture of Human Pluripotent Stem Cells. Cell Reports 10:537-550. https://doi.org/10.1016/j.celrep.2014.12.051

NAIT-OUMESMAR B., PICARD-RIERA N., KERNINON C., DECKER L., SEILHEAN D., HÖGLINGER G. U., HIRSCH E. C., REYNOLDS R., BARON-VAN EVERCOOREN A. (2007). Activation of the subventricular zone in multiple sclerosis: Evidence for early glial progenitors. Proceedings of the National Academy of Sciences 104: 4694-4699. https://doi.org/10.1073/pnas.0606835104

NARAYAN P., SIENSKI G., BONNER J. M., LIN Y.T., SEO J., BARU V., HAQUE A., MILO B., AKAY L. A., GRAZIOSI A., FREYZON Y., LANDGRAF D., HESSE W. R., VALASTYAN J., BARRASA M. I., TSAI L.H., LINDQUIST S. (2020). PICALM Rescues Endocytic Defects Caused by the Alzheimer's Disease Risk Factor APOE4. Cell Reports 33: 108224. https://doi.org/10.1016/j.celrep.2020.108224

NGUYEN H. N., BYERS B., CORD B., SHCHEGLOVITOV A., BYRNE J., GUJAR P., KEE K., SCHÜLE B., DOLMETSCH R. E., LANGSTON W., PALMER T. D., PERA R. R. (2011). LRRK2 Mutant iPSC-Derived DA Neurons Demonstrate Increased Susceptibility to Oxidative Stress. Cell Stem Cell 8: 267-280. https://doi.org/10.1016/j. stem.2011.01.013

NOLBRANT S., HEUER A., PARMAR M., KIRKEBY A. (2017). Generation of highpurity human ventral midbrain dopaminergic progenitors for in vitro maturation and intracerebral transplantation. Nature Protocols 12: 1962-1979. https://doi. org/10.1038/nprot.2017.078

OGAWA J., PAO G. M., SHOKHIREV M. N., VERMA I. M. (2018). Glioblastoma Model Using Human Cerebral Organoids. Cell Reports 23: 1220-1229. https:// doi.org/10.1016/j.celrep.2018.03.105

OKSANEN M., PETERSEN A. J., NAUMENKO N., PUTTONEN K., LEHTONEN Š, GUBERT OLIVÉ M., SHAKIRZYANOVAA., LESKELÄS., SARAJÄRVIT., VIITANEN M., RINNE J. O., HILTUNEN M., HAAPASALO A., GINIATULLINR., TAVIP.,ZHANG S.C., KANNINEN K. M., HÄMÄLÄINEN R. H., KOISTINAHO J. (2017). PSEN1 Mutant iPSC-Derived Model Reveals Severe Astrocyte Pathology in Alzheimer's Disease. Stem Cell Reports 9: 1885-1897. https://doi.org/10.1016/j.stemcr.2017.10.016

ORMEL P. R., VIEIRA DE SÁ R., VAN BODEGRAVEN E. J., KARST H., HARSCHNITZ O., SNEEBOER M. A. M., JOHANSEN L. E., VAN DIJK R. E., SCHEEFHALS N., BERDENIS VAN BERLEKOM A., RIBES MARTÍNEZ E., KLING S., MACGILLAVRY H. D., VAN DEN BERG L. H., KAHN R. S., HOL E. M., DE WITTE L. D., PASTERKAMP R. J. (2018). Microglia innately develop within cerebral organoids. Nature Communications 9: 4167. https://doi.org/10.1038/s41467-018-06684-2

OTTOBONI L., VON WUNSTER B., MARTINO G. (2020). Therapeutic Plasticity of Neural Stem Cells. Frontiers in Neurology 11: 148. https://doi.org/10.3389/ fneur.2020.00148

PAPASTEFANAKI F., CHEN J., LAVDAS A. A., THOMAIDOU D., SCHACHNER M., MATSAS R. (2007). Grafts of Schwann cells engineered to express PSA-NCAM promote functional recovery after spinal cord injury. Brain 130:2159-2174. https:// doi.org/10.1093/brain/awm155

PAPASTEFANAKI F., JAKOVCEVSKI I., POULIA N., DJOGO N., SCHULZ F., MARTINOVIC T., CIRIC D., LOERS G., VOSSMEYER T., WELLER H., SCHACHNER M., MATSAS R. (2015). Intraspinal Delivery of Polyethylene Glycol-coated Gold Nanoparticles Promotes Functional Recovery After Spinal Cord Injury. Molecular Therapy 23: 993-1002. https://doi.org/10.1038/mt.2015.50

PAREDES M. F., SORRELLS S. F., CEBRIAN-SILLA A., SANDOVAL K., QI D., KELLEY K. W., JAMES D., MAYERS., CHANG J., AUGUSTE K. I., CHANG E. F., GUTIERREZ MARTIN A. J., KRIEGSTEIN A. R., MATHERN G. W., OLDHAM M. C., HUANG E. J., GARCIA-VERDUGO J. M., YANG Z., ALVAREZ-BUYLLA A. (2018). Does Adult Neurogenesis Persist in the Human Hippocampus?. Cell Stem Cell 23: 780-781. https://doi.org/10.1016/j.stem.2018.11.006

PARFITT D. A., LANE A., RAMSDEN C. M., CARR A.J. F., MUNRO P. M., JOVANOVIC K., SCHWARZ N., KANUGA N., MUTHIAH M. N., HULL S., GALLO J.M., DA CRUZ L., MOORE A. T., HARDCASTLE A. J., COFFEY P. J., CHEETHAM M. E. (2016). Identification and Correction of Mechanisms Underlying Inherited Blindness in Human iPSC-Derived Optic Cups. Cell Stem Cell 18: 769-781. https://doi. org/10.1016/j.stem.2016.03.021

PARK J., WETZEL I., MARRIOTT I., DRÉAU D., D'AVANZO C., KIM D. Y., TANZI R. E., $\mathrm{CHO} \mathrm{H.} \mathrm{(2018).} \mathrm{A} \mathrm{3D} \mathrm{human} \mathrm{triculture} \mathrm{system} \mathrm{modeling} \mathrm{neurodegeneration} \mathrm{and}$ neuroinflammation in Alzheimer's disease. Nature Neuroscience 21: 941-951. https://doi.org/10.1038/s41593-018-0175-4

PELLEGRINI L., BONFIO C., CHADWICK J., BEGUM F., SKEHEL M., LANCASTER M. A. (2020). Human CNS barrier-forming organoids with cerebrospinal fluid production. Science 369: eaaz5626. https://doi.org/10.1126/science.aaz5626
POLITIS P. K., MAKRI G., THOMAIDOU D., GEISSEN M., ROHRER H., MATSAS R (2007). BM88/CEND1 coordinates cell cycle exit and differentiation of neuronal precursors. Proceedings of the National Academy of Sciences 104: 17861-17866. https://doi.org/10.1073/pnas.0610973104

PONROY BALLY B., FARMER W. T., JONES E. V., JESSA S., KACEROVSKY J. B., MAYRAN A., PENG H., LEFEBVRE J. L., DROUIN J., HAYER A., ERNST C. MURAI K. K. (2020). Human iPSC-derived Down syndrome astrocytes display genome-wide perturbations in gene expression, an altered adhesion profile, and increased cellular dynamics. Human Molecular Genetics 29: 785-802. https://doi. org $/ 10.1093 / \mathrm{hmg} / \mathrm{ddaa003}$

PRODROMIDOU K., MATSAS R. (2019). Species-Specific miRNAs in Human Brain Development and Disease. Frontiers in Cellular Neuroscience 13: 559. https://doi. org/10.3389/fncel.2019.00559

PRODROMIDOU K., PAPASTEFANAKI F., SKLAVIADIS T., MATSAS R. (2014). Functional Cross-Talk Between the Cellular Prion Protein and the Neural Cell Adhesion Molecule is Critical for Neuronal Differentiation of Neural Stem/Precursor Cells. Stem Cells 32: 1674-1687. https://doi.org/10.1002/stem.1663

PRODROMIDOU K., VLACHOSI. S., GAITANOU M., KOUROUPI G., HATZIGEORGIOU A. G., MATSAS R. (2020). MicroRNA-934 is a novel primate-specific small noncoding RNA with neurogenic function during early development. eLife 9: e50561. https://doi.org/10.7554/eLife.50561

QIAN X., JACOB F., SONG M. M., NGUYEN H. N., SONG H., MING G. (2018). Generation of human brain region-specific organoids using a miniaturized spinning bioreactor. Nature Protocols 13: 565-580. https://doi.org/10.1038/nprot.2017.152

QIAN X., NGUYEN H. N., SONG M. M., HADIONO C., OGDEN S. C., HAMMACK C., YAO B., HAMERSKY G. R., JACOB F., ZHONG C., YOON K., JEANG W., LIN L., LI Y., THAKOR J., BERG D. A., ZHANG C., KANG E., CHICKERING M., NAUEN D., HO C.Y., WEN Z., CHRISTIAN K. M., SHI P.Y., MAHER B. J., WU H., JIN P., TANG H., SONG H., MING G. (2016). Brain-Region-Specific Organoids Using Mini-bioreactors for Modeling ZIKV Exposure. Cell 165: 1238-1254. https://doi. org/10.1016/j.cell.2016.04.032

QUADRATO G., NGUYEN T., MACOSKO E. Z., SHERWOOD J. L., MIN YANG S., BERGER D. R., MARIA N., SCHOLVIN J., GOLDMAN M., KINNEY J. P., BOYDEN E. S., LICHTMAN J. W., WILLIAMS Z. M., MCCARROLL S. A., ARLOTTA P. (2017). Cell diversity and network dynamics in photosensitive human brain organoids. Nature 545: 48-53. https://doi.org/10.1038/nature22047

REYNOLDS B. A., WEISS S. (1992). Generation of Neurons and Astrocytes from Isolated Cells of the Adult Mammalian Central Nervous System. Science 255 1707-1710. https://doi.org/10.1126/science.1553558

RYAN S. D., DOLATABADI N., CHAN S. F., ZHANG X., AKHTAR M. W., PARKER J., SOLDNER F., SUNICO C. R., NAGAR S., TALANTOVA M., LEE B., LOPEZ K., NUTTER A., SHAN B., MOLOKANOVA E., ZHANG Y., HAN X., NAKAMURA T., MASLIAH E., YATES J. R., NAKANISHI N., ANDREYEV A. Y., OKAMOTO S. JAENISCH R., AMBASUDHAN R., LIPTON S. A. (2013). Isogenic Human iPSC Parkinson's Model Shows Nitrosative Stress-Induced Dysfunction in MEF2-PGC1a Transcription. Cell 155: 1351-1364. https://doi.org/10.1016/j.cell.2013.11.009

SAKAGUCHI H., KADOSHIMA T., SOEN M., NARII N., ISHIDA Y., OHGUSHI M. TAKAHASHI J., EIRAKU M., SASAI Y. (2015). Generation of functional hippocampal neurons from self-organizing human embryonic stem cell-derived dorsomedial telencephalic tissue. Nature Communications 6: 8896. https://doi. org/10.1038/ncomms 9896

SATO T., VRIES R. G., SNIPPERT H. J., VAN DE WETERING M., BARKER N., STANGE D. E., VAN ES J. H., ABO A., KUJALA P., PETERS P. J., CLEVERS H. (2009). Single Lgr 5 stem cells build crypt-villus structures in vitro without a mesenchymal niche. Nature 459: 262-265. https://doi.org/10.1038/nature07935

SCHWEITZER J. S., SONG B., HERRINGTON T. M., PARK T.Y., LEE N., KO S., JEON J., CHA Y., KIM K., LI Q., HENCHCLIFFE C., KAPLITT M., NEFF C., RAPALINO O., SEO H., LEE I.H., KIM J., KIM T., PETSKO G. A., RITZ J., COHEN B. M., KONG S.W., LEBLANC P., CARTER B. S., KIM K.S. (2020). Personalized iPSC-Derived Dopamine Progenitor Cells for Parkinson's Disease. New England Journal of Medicine 382: 1926-1932. https://doi.org/10.1056/NEJMoa1915872

SERIO A., BILICAN B., BARMADA S. J., ANDO D. M., ZHAO C., SILLER R., BURR K., HAGHI G., STORY D., NISHIMURA A. L., CARRASCO M. A., PHATNANI H. P., SHUM C., WILMUT I., MANIATIS T., SHAW C. E., FINKBEINER S., CHANDRAN S. (2013). Astrocyte pathology and the absence of non-cell autonomy in an induced pluripotent stem cell model of TDP-43 proteinopathy. Proceedings of the National Academy of Sciences 110: 4697-4702. https://doi.org/10.1073/ pnas. 1300398110 
SLOAN S. A., DARMANIS S., HUBER N., KHAN T. A., BIREY F., CANEDA C., REIMER R., QUAKE S. R., BARRES B. A., PAŞCA S. P. (2017). Human Astrocyte Maturation Captured in 3D Cerebral Cortical Spheroids Derived from Pluripotent Stem Cells. Neuron 95: 779-790.e6. https://doi.org/10.1016/j.neuron.2017.07.035

SMITS L. M., REINHARDT L., REINHARDT P., GLATZA M., MONZEL A. S., STANSLOWSKY N., ROSATO-SIRI M. D., ZANON A., ANTONY P. M., BELLMANN J., NICKLAS S. M., HEMMER K., QING X., BERGER E., KALMBACH N., EHRLICH M., BOLOGNIN S., HICKS A. A., WEGNER F., STERNECKERT J. L., SCHWAMBORN J. C. (2019). Modeling Parkinson's disease in midbrain-like organoids. npj Parkinson's Disease 5: 5. https://doi.org/10.1038/s41531-019-0078-4

SOLDNER F., HOCKEMEYER D., BEARD C., GAO Q., BELL G. W., COOK E. G., HARGUS G., BLAK A., COOPER O., MITALIPOVA M., ISACSON O., JAENISCH R. (2009). Parkinson's Disease Patient-Derived Induced Pluripotent Stem Cells Free of Viral Reprogramming Factors. Cell 136: 964-977. https://doi.org/10.1016/j. cell.2009.02.013

STACHOWIAK E. K., BENSON C. A., NARLA S. T., DIMITRI A., CHUYE L. E. B., DHIMAN S., HARIKRISHNAN K., ELAHI S., FREEDMAN D., BRENNAND K. J., SARDER P., STACHOWIAK M. K. (2017). Cerebral organoids reveal early cortical maldevelopment in schizophrenia-computational anatomy and genomics, role of FGFR1. Translational Psychiatry 7: 6. https://doi.org/10.1038/s41398-017-0054-x

SVOBODA D. S., BARRASA M. I., SHU J., RIETJENS R., ZHANG S., MITALIPOVA M., BERUBE P., FU D., SHULTZ L. D., BELL G. W., JAENISCH R. (2019). Human iPSC-derived microglia assume a primary microglia-like state after transplantation into the neonatal mouse brain. Proceedings of the National Academy of Sciences 116: 25293-25303. https://doi.org/10.1073/pnas.1913541116

TAKAHASHI J. (2020). iPS cell-based therapy for Parkinson's disease: A Kyoto trial. Regenerative Therapy 13: 18-22. https://doi.org/10.1016/j.reth.2020.06.002

TAKAHASHI K., YAMANAKA S. (2006). Induction of Pluripotent Stem Cells from Mouse Embryonic and Adult Fibroblast Cultures by Defined Factors. Cell 126: 663-676. https://doi.org/10.1016/j.cell.2006.07.024

TAOUFIKE., KOUROUPI G., ZYGOGIANNI O., MATSASR. (2018). Synaptic dysfunction in neurodegenerative and neurodevelopmental diseases: an overview of induced pluripotent stem-cell-based disease models. Open Biology 8: 180138. https://doi. org/10.1098/rsob.180138

TCW J., WANG M., PIMENOVA A. A., BOWLES K. R., HARTLEY B. J., LACIN E., MACHLOVI S. I., ABDELAAL R., KARCH C. M., PHATNANI H., SLESINGER P. A., ZHANG B., GOATE A. M., BRENNAND K. J. (2017). An Efficient Platform for Astrocyte Differentiation from Human Induced Pluripotent Stem Cells. Stem Cell Reports 9: 600-614. https://doi.org/10.1016/j.stemcr.2017.06.018

THOMSON J. A., ITSKOVITZ-ELDOR J., SHAPIRO S. S., WAKNITZ M. A., SWIERGIEL J. J., MARSHALL V. S., JONES J. M. (1998). Embryonic Stem Cell Lines Derived from Human Blastocysts. Science 282: 1145-1147. https://doi.org/10.1126/ science.282.5391.1145

TRUDLER D., GHATAK S., LIPTON S. A. (2021). Emerging hiPSC Models for Drug Discovery in Neurodegenerative Diseases. International Journal of Molecular Sciences 22: 8196. https://doi.org/10.3390/ijms22158196
VELASCO S., KEDAIGLE A. J., SIMMONS S. K., NASH A., ROCHA M., QUADRATO G., PAULSEN B., NGUYEN L., ADICONIS X., REGEV A., LEVIN J. Z., ARLOTTA P. (2019). Individual brain organoids reproducibly form cell diversity of the human cerebral cortex. Nature 570: 523-527. https://doi.org/10.1038/s41586-019-1289-x

WANG M., ZHANG L., GAGE F. H. (2020). Modeling neuropsychiatric disorders using human induced pluripotent stem cells. Protein \& Cell 11: 45-59. https:// doi.org/10.1007/s13238-019-0638-8

WANG S., BATES J., LI X., SCHANZ S., CHANDLER-MILITELLO D., LEVINE C., MAHERALI N., STUDER L., HOCHEDLINGER K., WINDREM M., GOLDMAN S. A. (2013). Human iPSC-Derived Oligodendrocyte Progenitor Cells Can Myelinate and Rescue a Mouse Model of Congenital Hypomyelination. Cell Stem Cell 12: 252-264. https://doi.org/10.1016/j.stem.2012.12.002

XIANG Y., TANAKA Y., PATTERSON B., KANG Y.J., GOVINDAIAH G., ROSELAAR N., CAKIR B., KIM K.Y., LOMBROSO A. P., HWANG S.M., ZHONG M., STANLEY E. G., ELEFANTY A. G., NAEGELE J. R., LEE S.H., WEISSMAN S. M., PARK I.H. (2017). Fusion of Regionally Specified hPSC-Derived Organoids Models Human Brain Development and Interneuron Migration. Cell Stem Cell 21: 383-398.e7. https://doi.org/10.1016/j.stem.2017.07.007

YANG J., ZHAO H., MA Y., SHI G., SONG J., TANG Y., LI S., LI T., LIU N., TANG F., GU J., ZHANG L., ZHANG Z., ZHANG X., JIN Y., LE W. (2017). Early pathogenic event of Alzheimer's disease documented in iPSCs from patients with PSEN1 mutations. Oncotarget 8: 7900-7913. https://doi.org/10.18632/oncotarget.13776

YOON S.J., ELAHI L. S., PAȘCA A. M., MARTON R. M., GORDON A., REVAH O., MIURA Y., WALCZAK E. M., HOLDGATE G. M., FAN H. C., HUGUENARD J. R., GESCHWIND D. H., PAȘCA S. P. (2019). Reliability of human cortical organoid generation. Nature Methods 16: 75-78. https://doi.org/10.1038/ s41592-018-0255-0

ZHANG S.C., WERNIG M., DUNCAN I. D., BRÜSTLE O., THOMSON J. A. (2001). In vitro differentiation of transplantable neural precursors from human embryonic stem cells. Nature Biotechnology 19: 1129-1133. https://doi.org/10.1038/ nbt1201-1129

ZHAO C., DENG W., GAGE F. H. (2008). Mechanisms and Functional Implications of Adult Neurogenesis. Cell 132: 645-660. https://doi.org/10.1016/j. cell.2008.01.033

ZHAO J., DAVIS M. D., MARTENS Y. A., SHINOHARA M., GRAFF-RADFORD N. R., YOUNKIN S. G., WSZOLEK Z. K., KANEKIYO T., BU G. (2017). APOE $\varepsilon 4 / \varepsilon 4$ diminishes neurotrophic function of human iPSC-derived astrocytes. Human Molecular Genetics 26: 2690-2700. https://doi.org/10.1093/hmg/ddx155

ZHAO J., FU Y., YAMAZAKI Y., REN Y., DAVIS M. D., LIU C.C., LU W., WANG X., CHEN K., CHERUKURI Y., JIA L., MARTENS Y. A., JOB L., SHUE F., NGUYEN T. T., YOUNKIN S. G., GRAFF-RADFORD N. R., WSZOLEK Z. K., BRAFMAN D. A., ASMANN Y. W., ERTEKIN-TANER N., KANEKIYO T., BU G. (2020). APOE4 exacerbates synapse loss and neurodegeneration in Alzheimer's disease patient iPSC-derived cerebral organoids. Nature Communications 11: 5540. https://doi. org/10.1038/s41467-020-19264-0 